\title{
REDISCOVERY OF PSEUDOPHILAUTUS HYPOMELAS (GÜNTHER, 1876) (AMPHIBIA: ANURA: RHACOPHORIDAE) FROM THE PEAK WILDERNESS, SRI LANKA, A SPECIES THOUGHT TO BE EXTINCT!
}

\section{L.J. Mendis Wickramasinghe ${ }^{1}$, Dulan Ranga Vidanapathirana ${ }^{2}$, M.D. Gehan Rajeev ${ }^{3}$ \& Nethu Wickramasinghe ${ }^{4}$}

ISSN

Online 0974-7907 Print 0974-7893

\footnotetext{
1,2,3,4 Herpetological Foundation of Sri Lanka, 31/5, Alwis Town, Hendala, Wattala, Sri Lanka

${ }^{1}$ boiga2000@gmail.com (corresponding author), ${ }^{2}$ dulanrangavp@gmail.com, ${ }^{3}$ gehanrajeev@gmail.com,

${ }^{4}$ nemzy821@gmail.com
}

Abstract: Pseudophilautus hypomelas (Günther, 1876), was previously known from the type collection of 14 specimens deposited in the Natural History Museum, London. There has been no record of this species since the original description by Günther in 1876 , and subsequently this species was considered extinct. In recent explorations however, the species has been rediscovered from the Peak Wilderness, Central Hills of Sri Lanka, with a rediscription of the species from fresh collections.

Keywords: Amphibia, Peak Wilderness, Pseudophilautus hypomelas, rediscovery, Sri Lanka, Sripada.

DOI: http://dx.doi.org/10.11609/JoTT.03547.5181-93 | ZooBank: urn:Isid:zoobank.org:pub:465BAFFC-87D5-41E3-94AF-CFE22D758AE2

Editor: S.K. Dutta, Indian Institute of Science, Bengaluru, India.

Date of publication: 26 December 2013 (online \& print)

Manuscript details: Ms \# 03547 | Received 03 March 2013 | Final received 12 November 2013 | Finally accepted 11 December 2013

Citation: Wickramasinghe, L.J.M., D.R. Vidanapathirana, M.D.G. Rajeev \& N. Wickramasinghe (2013). Rediscovery of Pseudophilautus hypomelas (Günther, 1876) (Amphibia: Anura: Rhacophoridae) from the Peak Wilderness, Sri Lanka, a species thought to be extinct!. Journal of Threatened Taxa 5(17): 5181-5193; http:// dx.doi.org/10.11609/JoTT.03547.5181-93

Copyright: @ Wickramasinghe et al. 2013. Creative Commons Attribution 3.0 Unported License. JoTT allows unrestricted use of this article in any medium, reproduction and distribution by providing adequate credit to the authors and the source of publication.

Funding: The Biodiversity Secretariat of the Ministry of Environment for funding and collaboration, the Nagao Natural Environment Foundation for part funding, the Department of Wildlife Conservation for permission granted (Permit No. WL/3/3/354), and the Dilmah Conservation for funding project activities.

Competing Interest: The authors declare no competing interests. Funding sources had no role in study design, data collection, results interpretation and manuscript writing.

Author Contribution: LJMW was involved in designing the study, conducting the field survey, conducting museum reference work, gathering, and analyzing the data, and compiling the MS. DRVP was involved in conducting the field survey, conducting NMSL museum reference work, gathering, analyzing the data, and writing the MS. MDGR was involved in conducting the field survey, conducting NMSL museum reference work, gathering, analyzing the data, and writing the manuscript. NW was involved in field research work and writing of the manuscript.

Acknowledgements: The authors wish to acknowledge the Biodiversity Secretariat of the Ministry of Environment for funding and for collaborating on the project, Mr. R.H.S.S. Samarathunga (Secretary-Ministry of Environment), Mr. Gamini Gamage (Additional Secretary-Policy Planning), Ms. Padma Abayakoon (Director), Mr. N.K.G.K. Nannawaththa (Additional Secretary-Natural Resources), Mr. R. A. R. Roopasinghe (Aditional Secretary- Administrations), Mr. Ajith de Silva (Former Director), Mrs. Dakshini Perera, and Mrs. Hasula Wickramasinghe for all the support rendered. To the Director General Mr. H. D. Rathnayake, and the Deputy Director Mr. S.R.B. Dissanayake (Research and Training) for all the suppport. Staff of the Nallathanniya beat specially to Mr. Anil Vithanage (Assistant Wildlife Ranger), and Palabaddala Wildlife beats. Mr. S. Chathuranga Ariyarathne, Mr. A.W. Amila Chanaka, Mr. L.L. Dharshana Priyantha, Mr. Gayan Chathuranga, Mr. Saman Gamage, Mr. Chaminda Pushpakumara, Mr. Dilshan Maduranga de Silva, Mr. E.A. Thusitha Jayanath, Mr. Lankaputhra Wimaladharma, Mr. L.P.D. Wasantha Kumara, Mr. Jagath Krishantha, Mr. Ruwan Chinthaka are thanked for their immense help in the field, and late Dr. Amith Munindradasa fondly remembered for his support and encouragement. The authors wish to acknowledge the contributions of Mr. Chamara Hettiarachchi, in preparing the location illustrations, to Mr. Charith Pubudu Lakmal and Mr. Lalith Senanayake for preparing images. The authors wish to thank the Directress National Museum of Sri Lanka, Mrs. Sanuja Kasthuriarachchi and staff members (Assistant Directress Mrs. Manori Nandasena, Mrs. Chandrika Munasinghe and Mrs. Manaram de Silva), are gratefully acknowledged for their assistance in museum reference work. Mr. Addison Wynn, Mr. Sameera Suranjan Karunarathna, Mr. Sanjiv de Silva provided valuable literature relevant for this work. We wish to thank Dr. Channa Bambaradeniya and Mr. Bhathiya Kekulandala for their valuable comments. The authors also like to thank their colleagues at Herpetological Foundation of Sri Lanka (HFS), for various courtesies. Thanks goes to Mr. Asanka Abayakoon for the encouragements, to Dr. Annemarie Ohler, and anonymous reviewers whose invaluable comments undoubtedly improved the quality of the paper. Finally, thanks are due to our principal sponsors Dilmah Conservation, for funding project activities.

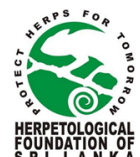

HERPETOLOGICAL

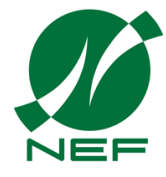

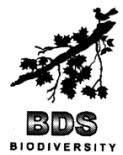

BIODIVERSIYY

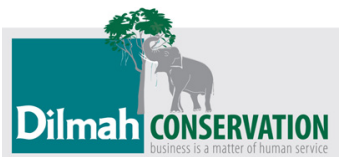




\section{INTRODUCTION}

Sri Lanka is home to 75 known species belonging to the genus Pseudophilautus. Currently, all the 75 species are endemic to the island (Manamendra-Arachchi \& Pethiyagoda 2005; Meegaskumbura \& ManamendraArachchi 2005, 2011; Meegaskumbura et al. 2007, 2009; Wickramasinghe et al. 2013a). Sri Lanka claims to have the highest number of extinct amphibians -19 species (Manamendra-Arachchi \& Pethiyagoda 1998, 2005; Manamendra-Arachchi \& de Silva 2004; Pethiyagoda 2005; IUCN \& MENR 2007; Meegaskumbura et al. 2007; Stuart et al. 2008; Manamendra-Arachchi \& Meegaskumbura 2012) and interestingly all belonging to the genus Pseudophilautus (ManamendraArachchi \& Pethiyagoda 2005; Meegaskumbura et al. 2007). Recently two species of frogs Adenomas kandianus Günther (1872) (Wickramasinghe et al. 2012) and, Pseudophilautus stellatus (Kelaart 1853) (Wickramasinghe et al. 2013b) were rediscovered from the Peak Wilderness.

Pseudophilautus hypomelas was only known from the syntype series deposited in the Natural History Museum, London (BMHH). Despite extensive field studies carried out over the past decade (ManamendraArachchi \& Pethiyagoda 2005) in Sri Lanka this species was reported to be extinct in the scientific literature (Manamendra-Arachchi \& Pethiyagoda 2005, IUCN \& MENR 2007; Bain et al. 2008; Chanson et al. 2008; Stuart et al. 2008; Manamendra-Arachchi \& Meegaskumbura 2012). The species was first described by Günther as Ixalus hypomelas, later Kirtisinghe (1957) synonymized the species with $P$. leucorhinus, but considering its well distinguishing characters Dutta \& Manamendra-Arachchi (1996), resurrected the species as Pseudophilautus hypomelas. Manamendra-Arachchi \& Pethiyagoda (2005) designated lectotype and para lectotypes from the syntypes of 14 specimens deposited at BMNH, most of which were in poor condition without having much information on external characters. Owing to the paucity of information, we conducted a survey in the Peak Wilderness Sanctuary of the Central Province, Sri Lanka and from our findings report the rediscovery of Pseudophilautus hypomelas, which was thought to be extinct.

The Peak Wilderness Sanctuary is one of the few remaining areas in Sri Lanka with a continuous natural forest with a cover of altitudinal graded forest types, ranging from lowland mixed dipterocarp forests to montane cloud forests and is an area of great biological diversity (Singhakumara 1995; ; Fernando \& Ranasinghe
1997). The Peak Wilderness Sanctuary, in particular, harbors a majority of the endemic and threatened bird species of Sri Lanka (Ranawana \& Bambaradeniya 1998; Wickramasinghe et al. 2007).

\section{MATERIALS AND METHODS}

The field survey was carried out in the Peak Wilderness, to assess the diversity of amphibians in an elevation gradient for over two years. The field survey commenced at the end of 2009, and phases I and II were completed in December 2011. The sampling sites were selected in a random manner considering accessibility and to cover representative habitats in the Nature Reserve, through an initial reconnaissance survey. Fifteen field visits were made with each sampling session spanning eight continuous days. Sampling was nocturnal, and photographs of most species were taken in the wild to avoid any confusion of change in colour during captivity. Specimens collected in the field were first fixed in $90 \%$ ethanol for two hours and stored in $70 \%$ ethanol.

Sex and maturity were determined by examining secondary sexual characters, or when absent, by examining the gonads through a small lateral incision in to the specimen. The material referred to is deposited in the Natural History Museum London (BMNH), and the National Museum, Sri Lanka (NMSL). Three specimens were collected for the current work and are deposited in the NMSL and the Girithale National Wildlife Research and Training Center (Department of Wildlife Conservation (DWC)).

The rediscovered species was compared with all types from Sri Lanka deposited in the NMSL, and type specimens deposited in the BMNH. The specimens formerly belonged to the Wildlife Heritage Trust (WHT) bearing WHT numbers and are currently deposited in the NMSL, catalogued under the same numbers.

Forty-four external measurements of specimens were taken with a Mitutoyo digital vernier calliper to the nearest $0.1 \mathrm{~mm}$. Terminology of external morphology abbreviated in the text and external measurements for the description section follows Wickramasinghe et al. (2013a).

Snout angle (Manamendra-Arachchi \& Pethiyagoda 2005) is not considered here due to an influence of preservation artifacts. Geographical coordinates were determined from GPS readings (Gamin eTrex Gista) with WGS84 (World Geodetic System) datum at the locality. 


\section{RESULTS AND DISCUSSION}

There are 14 specimens of $P$. hypomelas deposited in the BMNH collection, of which one specimen had been designated as a lectotype, mature female $20.9 \mathrm{~mm}$ SVL (BMNH 1947.2.27.8, collector-Beddome, localityCeylon) by Manamendra-Arachchi \& Pethiyagoda (2005). From the remaining 13 paralectotypes 11 were critically examined while the two remaining paralectotypes $\mathrm{BMNH}$ 1947.2.27.9, female specimens (19.7 SVL) and BMNH 1947.2.27.10 (20.7mm SVL) collected by W. Ferguson, from Ceylon were separately listed as 'others' (data not provided) in the same publication. Since all the 11 paralectotypes considered by Manamendra-Arachchi \& Pethiyagoda (2005) have been completely dried out, and the two specimens collected by W. Furguson are in better condition, we have considered only the latter in the present study. The lectotype and the two paralectotypes we consider here were originally registered in 1876 as lot BMNH 1876.3.21.31-33 Ixalus hypomela. They were re-registered in 1947 as BMNH 1947.2.27.8-10.

During a nocturnal sampling on the 06 April 2010, about 40 frogs resembling $P$. hypomelas were noticed from the Peak Wilderness Sanctuary $\left(06^{\circ} 48^{\prime} 28.02^{\prime \prime} \mathrm{N}\right.$ \& $80^{\circ} 28^{\prime} 14.46^{\prime \prime} \mathrm{E}$, elevation $1300 \mathrm{~m}$ ). Initially these frogs were thought to be new to science, of which only three specimens were collected to ascertain their taxonomic identity.

Careful museum studies confirmed the identity of the above collected specimens as Pseudophilautus hypomelas. Since the original description by Günther (Appendix 2) is precise here we redescribe the species with a report of rediscovery after a span of 137 years for scientific clarity of the species.

\section{Pseudophilautus hypomelas}

\section{Voucher specimen}

NMSL 2013.26.01 NH, adult female $22.4 \mathrm{~mm}$ SVL (Images 1; 2A,D), DWC 2013.01.014, adult female, SVL 21.1mm (Image 2 B\&E); DWC 2013.01.015, adult male, SVL 16.98mm (Images 2C,F; 3); Sripada (Peak Wilderness), Ratnapura District, Sabaragamuwa Province, Sri Lanka $\left(06^{\circ} 48^{\prime} 28.02^{\prime \prime} \mathrm{N} \& 80^{\circ} 28^{\prime} 14.46^{\prime \prime} \mathrm{E}\right)$, elevation $1300 \mathrm{~m}$ (Fig. 1). coll. L.J.M.W, D.R.V., M.D.G.R., S.C.A., \& A.W.A.C. 06.04.2010.

\section{Diagnosis}

The unique diagnostic character for the species is its markings on its dorsum; a pair of broad bronze longitudinal dorsal bands extends from the back of the eye to the groin, a bronze band between the eyes forms a prominent ' $T / \nabla$ ' shaped patch centrally projecting towards the vent which are unique markings for this species. Apart from the above, $P$. hypomelas can be distinguished from known congeners by the following combination of characters: body small size (adult male, SVL $16.98 \mathrm{~mm}$, adult females SVL 21.1-22.4mm); head dorsally and interorbital space convex; snout lateral acuminate; canthus rostralis rounded; internarial space flat; lingual papilla, fringe on fingers, calcar and nuptial pad absent; vomerine teeth absent; snout, interorbital area, side of head, anterior and posterior dorsum, lower and upperflank, throat and chest smooth; supernumerary tubercles on palm absent; supernumerary tubercles on foot absent.

\section{Description of NMSL 2013.26.01 NH}

Small size (SVL 22.4), elongate (SVL/HW 2.7); head large (HL/SVL 0.4), as wide as long (HW/HL 0.9); snout acuminate in lateral aspect (Fig. 2A), mucronate in dorsal (Fig. 2B) and pointed in ventral aspects (Fig. 2C) (ES/DFE 0.9, SN/IN 0.8), larger than horizontal diameter of eye (ES/ED 1.2); internasal space flat; canthus rostralis rounded, loreal region concave; interorbital space convex, larger than upper eyelid (IO/UEW 1.7), and internasal distance (IN/UEW 1.2); distance between front of eyes $3 / 5^{\text {th }}$ of the distance between back of eyes (DBE/DFE 1.6); nostrils oval, without flap of skin laterally, closer to tip of snout than to eye (SN/EN 0.6); pupil horizontally elliptical; tympanum distinct, vertically elliptical (TYH/TYW 1.6), smaller than the eye diameter (TYH/ED 0.4), tympanum-eye distance half of tympanum width (TAD/TYW 0.5); pineal ocellus absent; vomerine

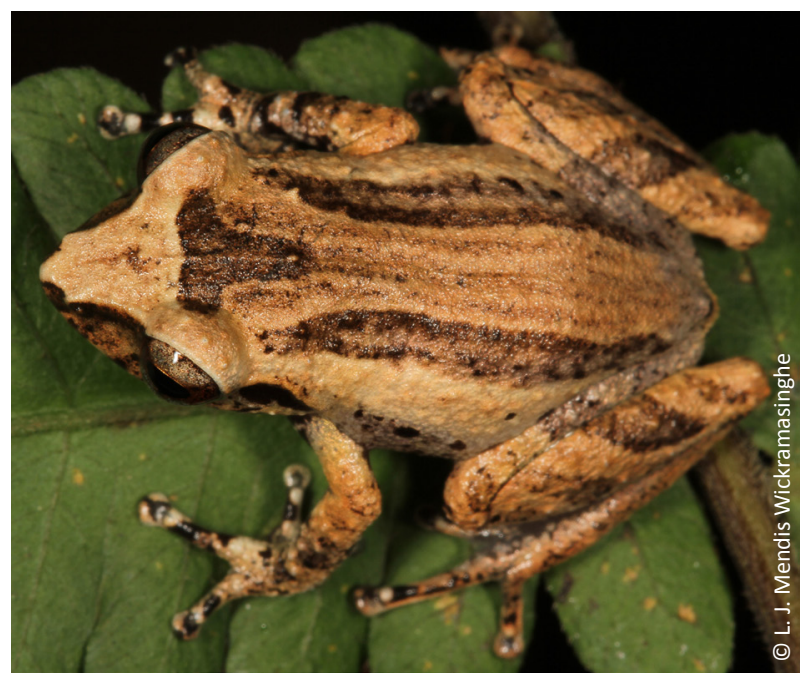

Image 1. Pseudophilautus hypomelas in life NMSL 2013.26.01 NH. 

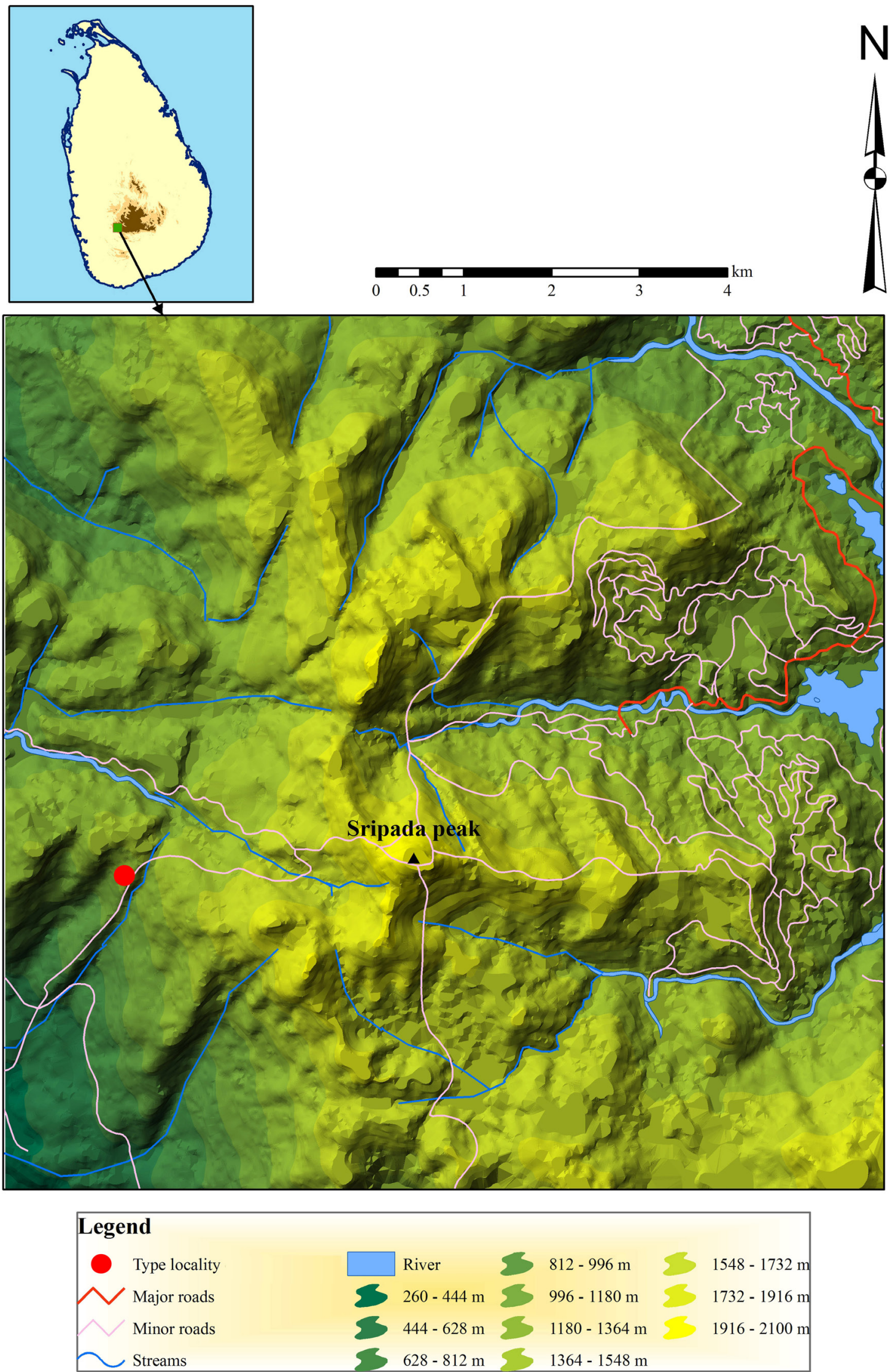

Figure 1. Tyepe locality details for Pseudophilautus hypomelas 


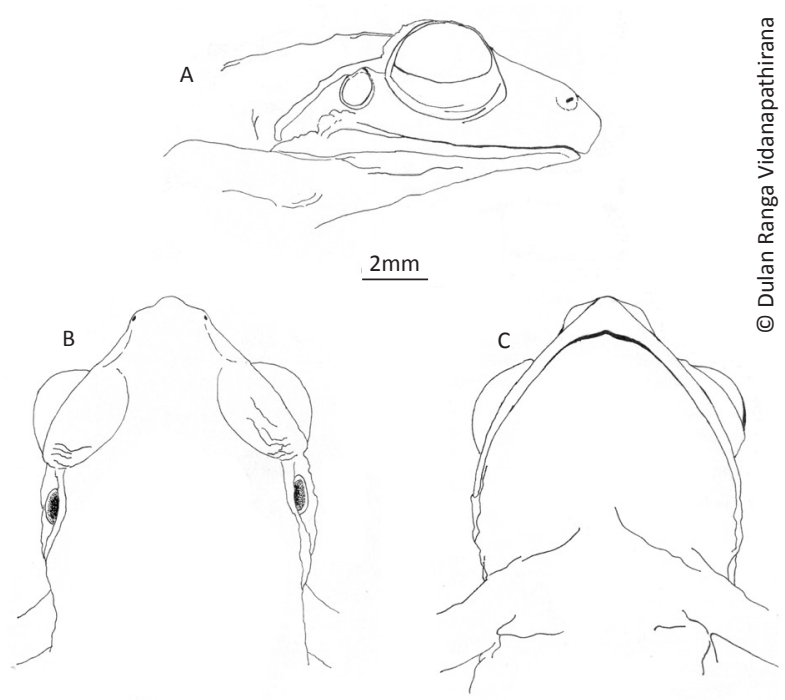

Figure 2. Pseudophilautus hypomelas head A - lateral aspect; B - dorsal aspect; C - ventral aspect.

teeth absent, small, few, odontophores oblique and widely separated, between choanae with an angle of $65^{\circ}$ relative to body axis; tongue small, tip bifurcate, and lanceolate; lingual papilla absent, but a few conical tubercles present on tongue.

Arm short, thin (LAL/FEL 0.5, UAL/FEL 0.4); forearm shorter than hand length (LAL/HNL 0.8), longer than upper arm (LAL/UAL 1.3); fingers thin, relative length of fingers I < II < IV < III (FL-1/FL-3 0.4, FL-2/FL-3 0.6, FL-4/ FL-3 0.8) (Table 1); tips of fingers rounded enlarged, discs present on all fingers, with distinct basal and circum marginal grooves; lateral dermal fringe absent on all fingers; webbing feeble, webbing formula $13-3 \| 3-3 \frac{1}{2}$ III2 2/3-3IV (Fig. 3A); subarticular tubercles prominent, rounded, single, all present, III2, and IV2 relatively smaller; inner palmar tubercle distinct, single, oval, larger than outer palmer tubercle; outer palmar tubercle distinct, single, oval, smaller than the distal subarticular tubercles; supernumerary tubercles absent on finger I, a few present on II, III, IV, and palm; prepollex absent; femur 1.5 times longer than fourth toe length (FEL/TL-4 1.5); foot length longer than thigh (FOL/FEL 1.4); toes thin, (Figure 3B), relative length of toes I $<$ II $<$ III $<$ V $<$ IV (TL-1/TL-4 0.2, TL-2/TL-4 0.3, TL-3/TL-4 0.4, TL-5/TL-4 $0.5)$; tips of toes rounded, enlarged, discs present on all toes with distinct basal and circum marginal grooves; webbing formula $12-2-112^{+}-3 I I 12-3-1 V 3-2 V$ (Fig. 3B); dermal fringe absent; subarticular tubercles prominent, rounded or oval and single, all present IV3 and V2 relatively smaller; supernumerary tubercles present; inner metatarsal tubercle oval prominent and large, its length $4 / 5^{\text {th }} \mathrm{S}$ in length of toe I (IML/TL-1 0.9); outer

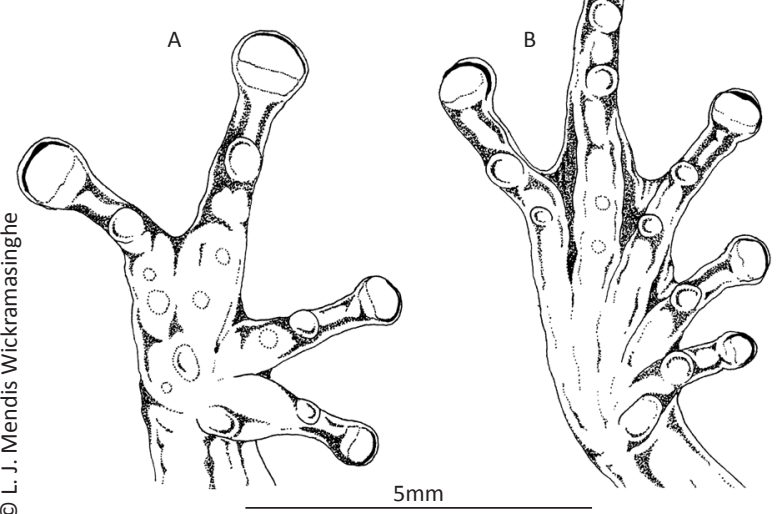

Figure 3. Pseudophilautus hypomelas NMSL 2013.26.01 NH A - ventral aspect of right hand; B - ventral aspect of right foot.

metatarsal tubercle present, small; tarsal fold, tarsal tubercles and calcar absent.

Skin on dorsal and lateral snout and between eyes smooth; upper eyelid smooth; head smooth laterally, shagreened near the gape of mouth; dorsum smooth; thin median dermal ridge on mid dorsum from tip of snout to back of head; upper and lower part of flank smooth; supratympanic fold prominent; upper arm smooth; forearm and hand smooth; inner, outer and dorsal thigh smooth; leg dorsally smooth; small tubercles present at heel; tarsus and foot smooth.

Ventral side of body: Throat and chest smooth; belly granular; forearm and upper arm smooth; thigh weakly granular; leg and tarsus smooth.

Colour in life: Dorsum cream colour, a pair of broad bronze longitudinal dorsal bands extends from the back of the eye to the groin, bronze band between the eyes forms a prominent ' $T$ ' shaped patch centrally projecting towards vent; laterally bronze band on canthal edge, bronze patch below eye, dark brown band below supratympanic fold; limbs dorsally cream, forelimb, hind limb, fingers and toes with bronze bands; ventrally off white with dark brown blotches, throat darker, belly off white, hands, feet, and webbing dark brown (Image 1).

Colour in alcohol: Colour pattern remains with a little fading, bronze changes to brown and off white to a yellowish tinge (Image $2 A, D$ ); ventral side blotching preserved with a little fading.

\section{Variations}

Dorsally yellowish, a prominent off white vertebral stripe from the tip of the snout to anus, and continuing down the hind limbs symmetrically (Image 3 ). In some 
Table 1. The morphometric measurements $(\mathrm{mm})$ of Pseudophilautus hypomelas. (* denotes absence or discontinuation due to damage)

\begin{tabular}{|c|c|c|c|c|c|c|c|c|c|}
\hline & \multicolumn{9}{|c|}{ P. hypomelas } \\
\hline & $\begin{array}{c}\text { BMNH } \\
1947.2 .27 .8\end{array}$ & $\begin{array}{c}\text { BMNH } \\
\text { 1947.2.27.9 }\end{array}$ & $\begin{array}{c}\text { BMNH } \\
\text { 1947.2.27.10 }\end{array}$ & $\begin{array}{c}\text { NMSL } \\
\text { 2013.26.01 NH }\end{array}$ & $\begin{array}{c}\text { DWC } \\
2013.01 .014\end{array}$ & $\begin{array}{c}\text { DWC } \\
2013.01 .015\end{array}$ & \multirow{2}{*}{ Mean } & \multirow{2}{*}{ SD } & \multirow{2}{*}{ Range } \\
\hline & Lectotype & Paralectotype & Paralectotype & $\begin{array}{l}\text { Voucher } \\
\text { specimen }\end{array}$ & $\begin{array}{l}\text { Voucher } \\
\text { specimen }\end{array}$ & $\begin{array}{l}\text { Voucher } \\
\text { specimen }\end{array}$ & & & \\
\hline DB & 0.3 & 0.2 & $0.0^{*}$ & 0.7 & 0.7 & 0.5 & 0.5 & 0.2 & $0.2-0.7$ \\
\hline DBE & 6.9 & 6.3 & 6.9 & 7.5 & 7.2 & 5.8 & 6.8 & 0.6 & $5.8-7.5$ \\
\hline DFE & 4.2 & 3.8 & 4.3 & 4.6 & 4.4 & 3.7 & 4.2 & 0.3 & $3.7-4.6$ \\
\hline $\mathrm{DL}$ & 0.5 & 0.5 & $0.0^{*}$ & 1.1 & 1.1 & 0.8 & 0.8 & 0.3 & $0.5-1.1$ \\
\hline DW & 0.6 & 0.6 & $0.0 *$ & 1.0 & 1.0 & 0.7 & 0.8 & 0.2 & $0.6-1.0$ \\
\hline ED & 3.1 & 3.0 & 3.0 & 3.4 & 3.2 & 2.4 & 3.0 & 0.3 & $2.4-3.4$ \\
\hline EN & 2.5 & 2.4 & 1.6 & 2.7 & 2.0 & 1.9 & 2.2 & 0.4 & $1.6-2.7$ \\
\hline ES & 3.4 & 3.4 & 3.3 & 4.0 & 3.4 & 2.9 & 3.4 & 0.3 & $2.9-4.0$ \\
\hline FEL & 11.3 & 11.2 & 11.4 & 9.8 & 10.0 & 8.3 & 10.3 & 1.1 & 8.3-11.4 \\
\hline FL-1 & 1.3 & 1.3 & $0.0^{*}$ & 1.5 & 1.7 & 1.3 & 1.4 & 0.2 & $1.3-1.7$ \\
\hline FL-2 & 1.6 & 1.6 & 1.5 & 2.2 & 2.0 & 2.0 & 1.8 & 0.3 & $1.5-2.2$ \\
\hline $\mathrm{FL}-3$ & $2.1^{*}$ & 2.6 & $0.0^{*}$ & 3.9 & 3.3 & 3.0 & 3.0 & 0.7 & $2.1-3.9$ \\
\hline FL-4 & 1.9 & 1.7 & $0.0^{*}$ & 3.0 & 2.5 & 2.4 & 2.3 & 0.5 & $1.7-3.0$ \\
\hline $\mathrm{FOL}$ & $10.9 *$ & $4.8^{*}$ & 11.8 & 14.2 & 14.6 & 12.0 & 12.7 & 1.6 & $10.9-14.6$ \\
\hline GK & 10.2 & 8.7 & 9.2 & 9.2 & 8.2 & 7.2 & 8.8 & 0.9 & $7.2-10.2$ \\
\hline HD & 3.9 & 3.9 & 4.2 & 4.6 & 4.2 & 3.5 & 4.0 & 0.3 & $3.5-4.6$ \\
\hline $\mathrm{HL}$ & 8.8 & 8.5 & 8.9 & 9.4 & 9.0 & 7.3 & 8.7 & 0.7 & $7.3-9.4$ \\
\hline $\mathrm{HW}$ & 7.1 & 6.8 & 7.4 & 8.3 & 7.7 & 6.0 & 7.2 & 0.7 & $6.0-8.3$ \\
\hline $\mathrm{IML}$ & 0.8 & 0.8 & 0.5 & 1.3 & 1.1 & 1.1 & 0.9 & 0.3 & $0.5-1.3$ \\
\hline IN & 2.4 & 2.1 & 2.5 & 2.1 & 2.1 & 1.8 & 2.2 & 0.2 & $1.8-2.5$ \\
\hline 10 & 3.7 & 3.3 & 3.1 & 3.0 & 2.8 & 2.4 & 3.0 & 0.4 & $2.4-3.7$ \\
\hline KT & 10.6 & 9.7 & 9.7 & 10.0 & 9.1 & 7.7 & 9.5 & 0.9 & 7.7-10.6 \\
\hline $\mathrm{HNL}$ & $4.0^{*}$ & 4.8 & $0.0^{*}$ & 5.8 & 5.2 & 4.2 & 4.8 & 0.7 & $4.0-5.8$ \\
\hline LAL & 4.7 & 3.7 & 3.7 & 4.7 & 4.9 & 4.1 & 4.3 & 0.5 & $3.7-4.9$ \\
\hline MBE & $1.6^{*}$ & 2.4 & 2.8 & 3.7 & 3.8 & 2.9 & 3.1 & 0.6 & $2.4-3.8$ \\
\hline MFE & $2.6^{*}$ & 4.8 & 5.5 & 6.8 & 6.7 & 5.4 & 5.8 & 0.9 & $4.8-6.8$ \\
\hline $\mathrm{MN}$ & 7.0 & 6.5 & 6.8 & 8.8 & 8.2 & 7.0 & 7.4 & 0.8 & $6.5-8.8$ \\
\hline SN & 1.3 & 1.5 & 1.5 & 1.6 & 1.6 & 1.2 & 1.4 & 0.2 & $1.3-1.6$ \\
\hline SVL & 20.5 & 20.2 & 21.0 & 22.4 & 21.1 & 17.0 & 20.4 & 1.7 & $17.0-22.4$ \\
\hline TAD & 0.6 & 0.5 & 0.6 & 0.6 & 0.6 & 0.5 & 0.5 & 0.0 & $0.5-0.6$ \\
\hline TAS & 7.7 & 7.6 & 7.8 & 7.0 & 6.7 & 5.9 & 7.1 & 0.7 & $5.9-7.8$ \\
\hline TBL & 11.9 & 11.5 & 11.5 & 11.2 & 10.7 & 9.0 & 11.0 & 0.9 & $9.0-11.9$ \\
\hline TL-1 & $0.0^{*}$ & $0.0^{*}$ & $0.0^{*}$ & 1.5 & 1.7 & 1.2 & 1.5 & 0.2 & $1.2-1.7$ \\
\hline TL-2 & $0.0^{*}$ & $0.0^{*}$ & $0.0^{*}$ & 1.9 & 1.7 & 1.5 & 1.7 & 0.2 & $1.5-1.9$ \\
\hline TL-3 & $0.0^{*}$ & $0.0^{*}$ & $0.0^{*}$ & 2.6 & 2.6 & 2.3 & 2.5 & 0.2 & $2.3-2.6$ \\
\hline TL-4 & $0.0^{*}$ & $0.0^{*}$ & $0.0^{*}$ & 6.7 & 4.7 & 3.5 & 5.0 & 1.6 & $3.5-6.7$ \\
\hline TL-5 & $0.0^{*}$ & $0.0^{*}$ & $0.0^{*}$ & 3.2 & 2.9 & 2.3 & 2.8 & 0.4 & $2.3-3.2$ \\
\hline TND & 5.5 & 5.2 & 5.3 & 5.9 & 5.6 & 4.8 & 5.4 & 0.4 & $4.8-6.0$ \\
\hline TPD & 3.8 & 3.5 & 3.9 & 3.9 & 3.9 & 3.1 & 3.7 & 0.3 & $3.1-3.9$ \\
\hline TYH & 0.9 & 0.8 & 0.7 & 1.2 & 1.4 & 1.1 & 1.0 & 0.2 & $0.7-1.4$ \\
\hline TYW & 0.7 & 0.6 & 0.8 & 1.1 & 1.2 & 0.9 & 0.9 & 0.2 & $0.6-1.2$ \\
\hline UAL & 3.8 & 3.8 & 3.4 & 3.6 & 3.6 & 3.0 & 3.5 & 0.3 & $3.0-3.8$ \\
\hline UEW & 1.3 & 1.1 & 1.4 & 1.7 & 1.8 & 1.3 & 1.4 & 0.2 & $1.1-1.8$ \\
\hline VKA & 9.1 & 9.9 & 10.5 & 8.5 & 8.8 & 6.9 & 8.9 & 1.2 & $6.9-10.5$ \\
\hline
\end{tabular}




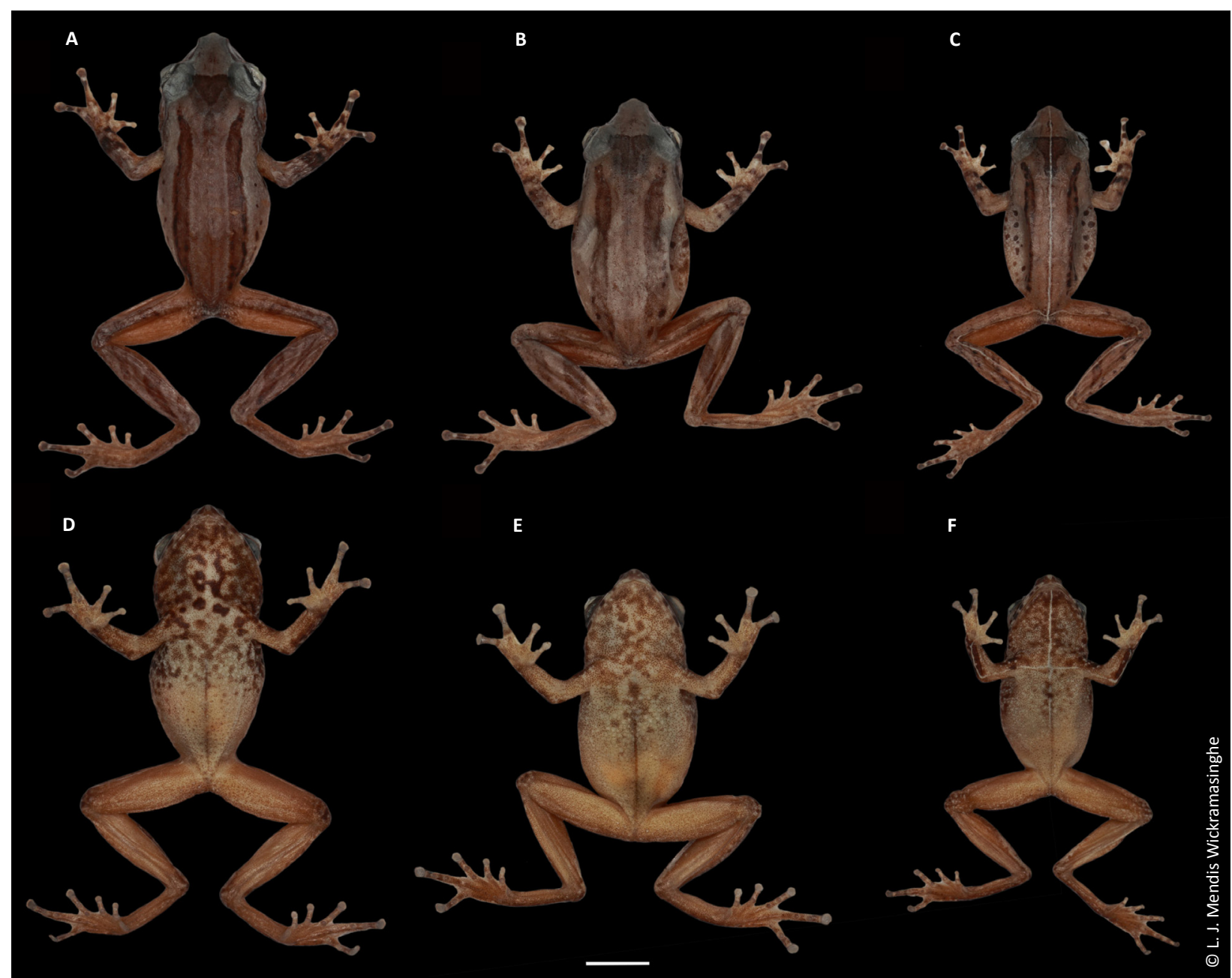

Image 2. Rediscovered specimen series of Pseudophilautus hypomelas Left to right, NMSL 2013.26.01 NH, DWC 2013.01.014, DWC 2013.01.015. A-C - dorsal aspect and D-F - ventral aspect. Scale: $5 \mathrm{~mm}$.

a mid ventral longitudinal white line from the tip of the chin to anus and another one perpendicular to it runs across the chest leading towards the forelimbs making a prominent cross marking.

\section{Natural history}

The species was found in elevations of 750-1400m in lower montane rain forests (Fig. 1). Commonly observed in bushes of less than $1 \mathrm{~m}$ high, and preferred grassy habitats with a less canopy cover such as those in disturbed areas.

$P$. hypomelas was identified by its identical resemblance to the material found in the $\mathrm{BMNH}$ with its comparable sizes, smooth skin, similar ratios of morphometric measurements, above all by the marking on head (Image $4 \mathrm{~A}-\mathrm{C}$ ), and the blotching on ventral

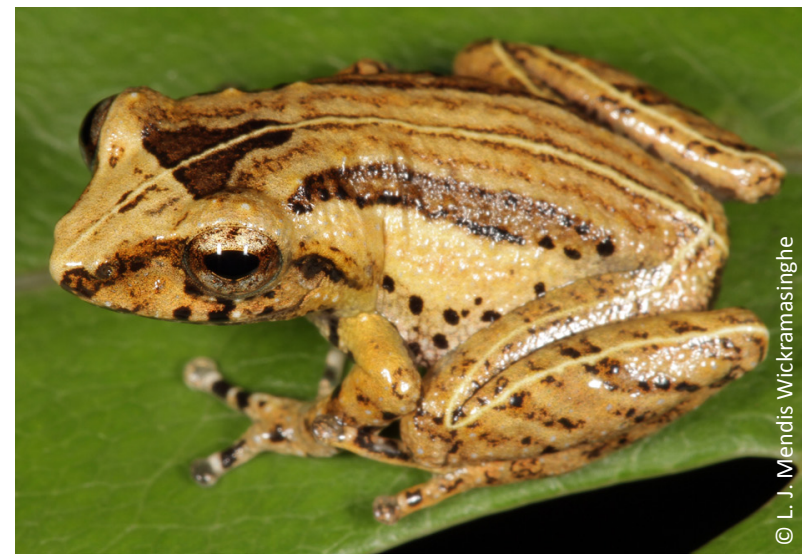

Image 3. A prominent off white vertebral stripe from the tip of the snout to anus, and continuing down the hind limbs symmetrically of Pseudophilautus hypomelas in life DWC 2013.01.015. side (Image $4 \mathrm{D}-\mathrm{F}$ ) which are still preserved in the type material confirming its identity. Apart from which, in 


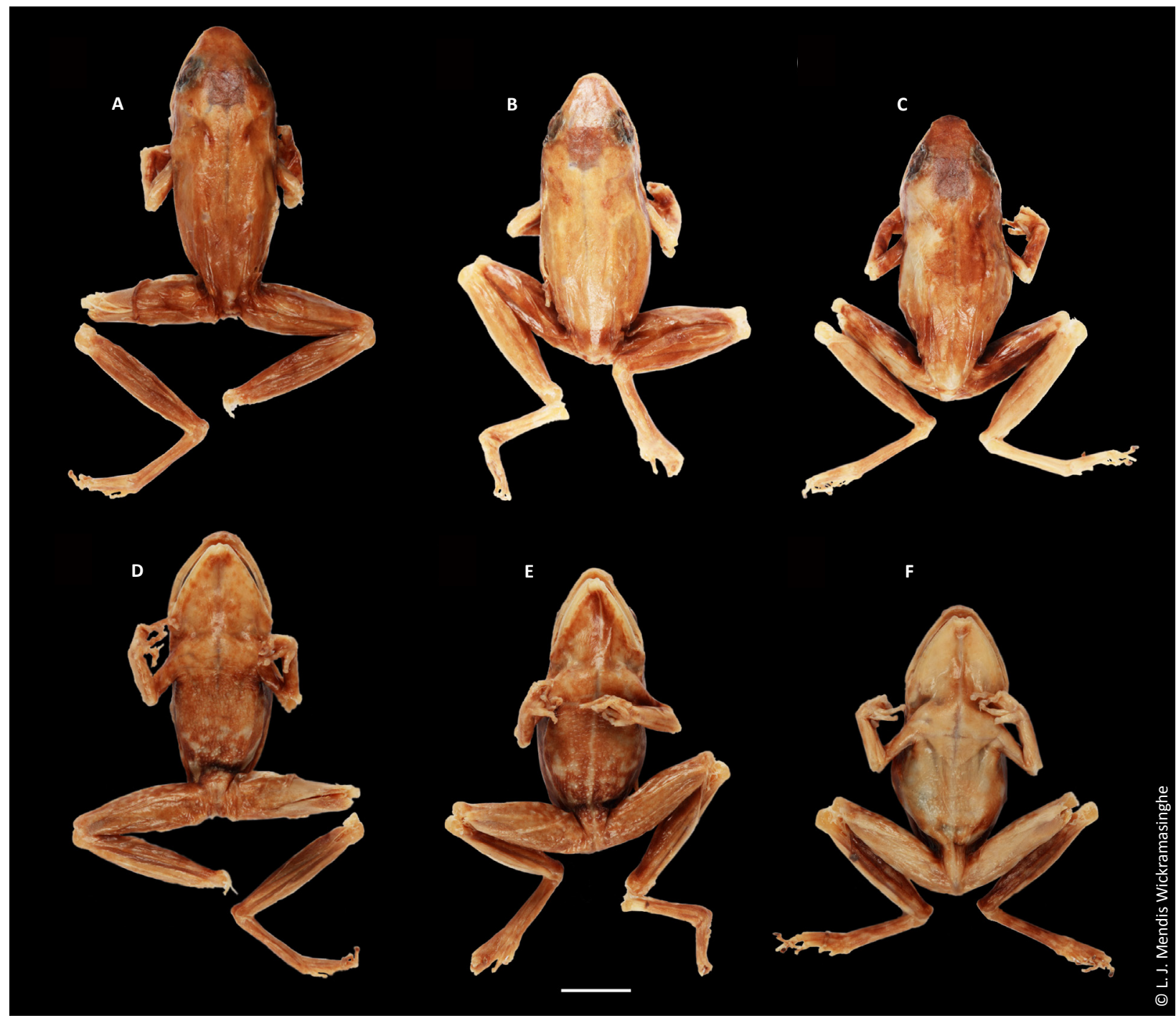

Image 4. Type series of Pseudophilautus hypomelas, from left to right, lectotype BMNH 1947.2.27.8, paralectotype BMNH 1947.2.27.9, and paralectotype BMNH 1947.2.27.10; A-C dorsal aspect and D-F ventral aspect.

some collected material a prominent cross marking was noticed on the ventral side (Image 5A) as mentioned in variations section; interestingly this marking was also seen in some type material specimens (Image 5B). Also the type description mentions "a fine white line runs along the middle of the back and of the abdomen, beginning from the snout....." (Image 3), and Günther also states that all or some of these lines may be absent, which is true for some specimens (mentioned under variations) which did not possess these lines. In the original type description Günther erroneously states that its "tympanum hidden", "Fingers not webbed; web of the hind foot rudimentary", but a distinct tympanum can be seen (Image 6) in all the specimens found in the $\mathrm{BMNH}$, and in our specimens, also the webbing formula of fingers are $13-3 \| 3-3 \quad \frac{1}{2}$ IIII $2 / 3-3$ IV (Fig. $3 \mathrm{~A})$; toes $12-2-112^{+}-3 \mathrm{III}-3-\mathrm{IV} 3-2 \mathrm{~V}$ (Fig. 3B). Dutta \& Manamendra-Arachchi (1996), states that the species possesses rudimentary webbing on toes but again in 2005, Manamendra-Arachchi \& Pethiyagoda states that P. hypomelas, "Toes free (webbing absent)". Although the toes of the lectotype specimen is in poor condition on close observation the rudimentary webbing can still be determined (Image 7).

A description of the species along with a distribution was last provided by Manamendra-Arachchi \& Dutta in 1996, which states; "apart from the syntype specimens, the species has been recorded from 1800m Kandy", however the photograph of a live frog provided, 'Figure 165 ', was erroneous and not a specimen of $P$. hypomelas, 


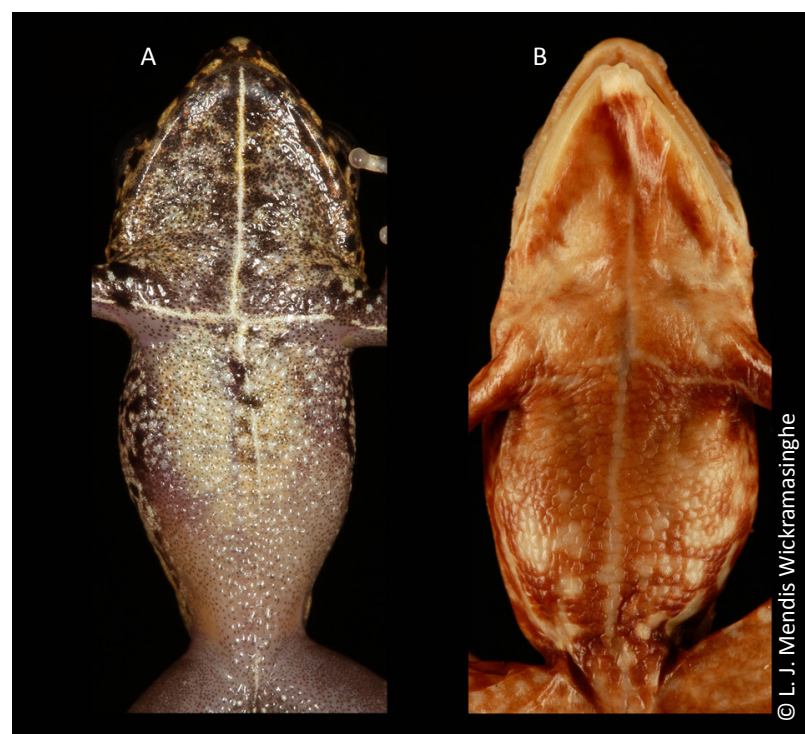

Image 5. Comparison of the prominent off white, symmetrical cross on the ventral side of Pseudophilautus hypomelas.

A - in life DWC 2013.01.015; B - paralectotype of BMNH 1947.2.27.9

but the 'Figure 164' of a syntype specimen clearly shows its dried out condition. Interestingly, one of the above authors in 2005 stated that $P$. hypomelas was extinct for the reason that they had never encountered the species from their 10 years of Island-wide survey.

Although the type locality for the species at the BMNH is mentioned as "Ceylon" (Sri Lanka), the locality of the two specimens provided by W. Ferguson in his "Reptile Fauna of Ceylon, Letter on a collection sent to the Colombo Museum", on page 29 states under point 164, that they were collected from Le Vallon Estate, Nilambe District. Presently, this area comes under the Nuwara Eliya District. Also in this same reference (Appendix 3) Ferguson mentions that the description of Ixalus hypomelas by Dr. Günther was based on specimens sent by Col. Beddome and himself. Above all, the statements clearly have the mention about specific identity of the 'type locality', in spite of this and without making an effort to searching this species from 'type locality' the scientific community had concluded the species to be extinct.

The conservation status of this species redescribed here, should be considered as Critically Endangered under the IUCN Red List Categories and Criteria because of the extent of occurrence (EOO) is less than $100 \mathrm{~km}^{2}$, the area of occupancy (AOO) is less than $10 \mathrm{~km}^{2}$, and is recorded from a single location. The habitat is under severe anthropogenic activities such as over exploitation of natural resources for tea cultivation, forest fragmentation, use of agrochemicals, soil

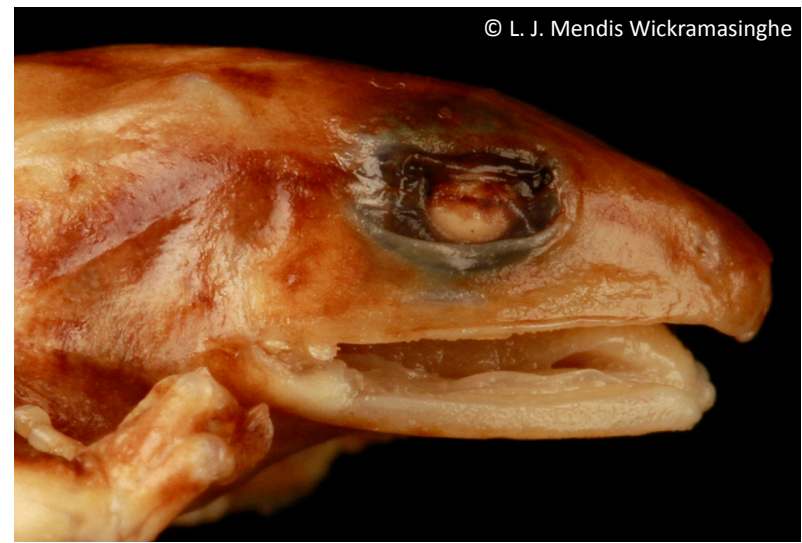

Image 6. The tympanum of lectotype of Pseudophilautus hypomelas BMNH 1947.2.27.9

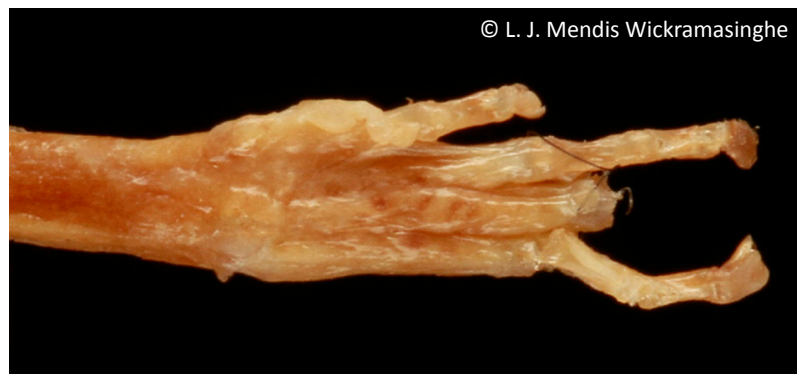

Image 7. The webbing of lectotype of Pseudophilautus hypomelas BMNH 1947.2.27.9

erosion, inadequately planned constructions and illegal constructions, mini-hydro power plants, forest die back, and discharge of pollutants to the environment. There seems to be an ambiguity with the type locality from the literature for $P$. hypomelas and our collections from a different locality could be considered as an undescribed species owing to the fact of high levels of point endemism within Sri Lanka, but we take the most parsimonious solution of fixing our collections as $P$. hypomelas due to its overall resemblance in morphology to stabilize the taxonomy for this species.

\section{REFERENCES}

Bain, R.S.D., B.R. Brown, I. Das, A. Diesmos, S. Dutta, D. Gower, R. Inger, D. Iskandar, Y. Kaneko, M.W.N. Lau, M. Meegaskumbura, A. Ohler, T. Papenfuss, R. Pethiyagoda, B. Stuart, M. Wilkinson \& F. Xie (2008). Amphibians of the Indomalayan realm, pp 74-79. In: Stuart, S.N., M. Hoffmann, J.S. Chanson, N.A., Cox, R.J. Berridge, P. Ramani \& B.E. Young (eds.). Threatened Amphibians of the World. Lynx Editions, xv+776pp.

Chanson, J., M. Hoffmann, N. Cox \& S. Stuart (2008). The state of the world's amphibians, pp. 33-44. In: Stuart, S.N., M. Hoffmann, J.S. Chanson, N.A. Cox, R.J. Berridge, P. Ramani \& B.E. Young (eds.). Threatened Amphibians of the World. Lynx Editions, xv+776pp. 
Dutta, S.K. \& K. Manamendara-Arachchi (1996). The Amphibian Fauna of Sri Lanka. Wildlife Heritage Trust of Sri Lanka, Colombo, 232pp.

DWC (2007). Biodiversity Baseline Survey: Peak Wilderness Sanctuary. Consultancy Services Report prepared by Green, M.J.B. (ed.), De Alwis, S.M.D.A.U., Dayawansa, P.N., How, R., Singhakumara, B.M.P., Weerakoon, D. and Wijesinghe, M.R. ARD Inc in association with Infotech IDEAS and GREENTECH Consultants. Sri Lanka Protected Areas Management and Wildlife Conservation Project (PAM\&WCP) CONSULT/02/BDBS), Department of Wildlife Conservation, Ministry of Environment and Natural Resources, Colombo, 1-44pp.

IUCN Sri Lanka \& Ministry of Environment and Natural Resources Sri Lanka (2007). The 2007 National Red List of Threatened Fauna and Flora of Sri Lanka. IUCN Sri Lanka and Ministry of Environment and Natural Resources Sri Lanka, 148pp.

Günther, A. (1876). Notes on the mode of propagation of some Ceylonese Tree-frogs, with description of two new species. Annals and Magazine of natural History (4)17: 377-380.

Grosjean, S., M. Delorme, A. Dubois \& A. Ohler (2008). Evolution of reproduction in the Rhacophoridae (Amphibia, Anura). Journal of Zoological Systematics and Evolutionary Research 46(2): 169-176.

Kirtisinghe, P. (1957). The Amphibia of Ceylon. Published by Author, Colombo, 112pp.

Li, J., J. Che, R.H. Bain, E. Zhao \& Y. Zhang (2008). Molecular phylogeny of Rhacophoridae (Anura): a framework of taxonomic reassignment of species within the genera Aquixalus, Chiromantis, Rhacophorus and Philautus. Molecular Phylogenetics and Evolution 48: 302-312.

Li, J., J. Che, R.W. Murphy, H. Zhao, E. Zhao, D. Rao \& Y. Zhang (2009). New insights to the molecular phylogenetics and generic assessment in the Rhacophoridae (Amphibia: Anura) based on five nuclear and three mitochondrial genes, with comments on the evolution of reproduction. Molecular Phylogenetics and Evolution 53: 509-522.

Manamendra-Arachchi, K. \& M. Meegaskumbura (2012). Taxonomy and Conservation Status of Amphibians in Sri Lanka, pp. 88-98. In: Weerakoon, D.K. \& S. Wijesundara (eds.). The National Red List 2012 of Sri Lanka. Conservation Status of the Fauna and Flora. Ministry of Environment, Colombo, Sri Lanka, xxi+451pp.

Manamendra-Arachchi, K. \& R. Pethiyagoda (1998). A synopsis of the Sri Lankan Bufonidae (Amphibia: Anura) with description of new species. Journal of South Asian Natural History 3: 213-248.

Manamendra-Arachchi, K. \& R. Pethiyagoda (2005). The Sri Lankan Shrub-frogs of the genus Philautus Gistel, 1848 (Ranidae: Rhacophorinae) with description of 27 new species. The Rafels Bulletin of Zoology 12: 163-303.

Manamendra-Arachchi, K. \& A. de Silva (2004). Pseudophilautus hypomelas. In: IUCN 2012. IUCN Red List of Threatened Species. Version 2012.2. <www.iucnredlist.org>. (accessed 28 January 2012).
Meegaskumbura, M. \& K. Manamendra-Arachchi (2005). Description of eight new species of Shrub-frogs (Ranidae: Rhacophorinae: Philautus) from Sri Lanka. The Raffles Bulletin of Zoology 12: 305338.

Meegaskumbura, M. \& K. Manamendra-Arachchi (2011). Two new species of shrub frogs (Rhacophoridae: Pseudophilautus) from Sri Lanka. Zootaxa 2747: 1-18.

Meegaskumbura, M., K. Manamendra-Arachchi \& R. Pethiyagoda (2009). Two new species of shrub frogs (Rhacophoridae: Philautus) from the lowlands of Sri Lanka. Zootaxa 2122: 51-68.

Meegaskumbura, M., K. Manamendra-Arachchi, C.J. Schneider \& R. Pethiyagoda (2007). New species amongst Sri Lanka's extinct shrub frogs. Zootaxa 1397: 1-15.

Pethiyagoda, R. (2005). Exploring Sri Lanka's biodiversity. The Raffles Bulletin of Zoology 12: 1-4.

Ranawana, K.B. \& C.N.B. Babaradeniya (1998). Species composition, status and feeding ecology of avifauna in high altitude forest of Sri Lanka. Journal of Bombay Natural History Society 95(3): 392-407.

Singhakumara, B.M.P. (1995). Floristic survey of Adam's peak wilderness. Sri Lanka Forest Departmnt, 1-156pp.

Stuart, S.N., M. Hoffmann, J.S. Chanson, N.A. Cox, R.J. Berridge, P. Ramani \& B.E. Young (2008). Threatened Amphibians of the World. Lynx Editions, 776pp.

Wickramasinghe, L.J.M., D.R. Vidanapathirana \& N. Wickramasinghe (2012). Back from the dead: The world's rarest toad Adenomus kandianus rediscovered in Sri Lanka. Zootaxa 3347: 63-68.

Wickramasinghe, L.J.M., D.R. Vidanapathirana, M.D.G. Rajeev, S.C. Ariyarathne, A.W.A. Chanaka, L.L.D. Priyantha, I.N. Bandara \& N. Wickramasinghe (2013a). Eight new species of Pseudophilautus (Amphibia, Anura, Rhacophoridae) from Sripada World Heritage Site (Peak Wilderness), a local amphibian hotspot in Sri Lanka. Journal of Threatened Taxa 5(4): 3789-3920; http://dx.doi.org/10.11609/ JoTT.03099.3789-920

Wickramasinghe, L.J.M., R. Rodrigo, N. Dayawansa \& U.L.D. Jayantha (2007). Two new species of Lankascincus (Squmamata: Scincidae) from Sripada Sanctuary (Peak Wilderness), in Sri Lanka. Zootaxa 1612: 1-24.

Wickramasinghe, L.J.M., D.R. Vidanapathirana, S. Ariyarathne, G. Rajeev, A. Chanaka, J. Pastorini, G. Chathuranga \& N. Wickramasinghe (2013b). Lost and found: One of the world's most elusive amphibian Pseudophilautus stellatus (Kelaart 1853) rediscovered. Zootaxa 3620(1): 112-128. 
Appendix 1. Material examined.

Pseudophilautus abundus (Manamendra-Arachchi \& Pethiyagoda, 2005). Holotype: WHT 3006; Labugama Forest Reserve, Labugama, elevation 78m (06 $\left.51^{\prime} \mathrm{N} \& 080^{\circ} 10^{\prime} \mathrm{E}\right)$; Paratypes: WHT 2302; 2303; 3457; 3459; 3494; 3496, Dediyagala Forest Reserve, Akuressa, elevation 150m $\left(06^{\circ} 10^{\prime} \mathrm{N} \& 080^{\circ} 26^{\prime} \mathrm{E}\right)$; WHT 1711; 3455; 3456; 3495, Kanneliya (Galle), elevation 150m (06 $\left.15^{\prime} \mathrm{N} \& 080^{\circ} 20^{\prime} \mathrm{E}\right)$.

Pseudophilautus adspersus (Günther, 1872). Holotype: BMNH 1947.2.6.23, Ceylon (Sri Lanka).

Pseudophilautus alto (Manamendra-Arachchi \& Pethiyagoda, 2005). Holotype: WHT 2721; Paratypes: WHT 2723; 2718; 2719; 2720; 2722; 2724; Horton Plains National Park, elevation $2135 \mathrm{~m}\left(06^{\circ} 46^{\prime} \mathrm{N}, 080^{\circ} 47^{\prime} \mathrm{E}\right)$.

Pseudophilautus asankai (Manamendra-Arachchi \& Pethiyagoda, 2005). Holotype: WHT 3507; Paratypes: WHT 3504; 3505; 3506; 5425, Agra Arboretum, Torrington Estate, near Agarapatana, elevation 1665m (06 $\left.50^{\prime} 36^{\prime \prime} \mathrm{N}, 80^{\circ} 40^{\prime} 40^{\prime \prime} \mathrm{E}\right)$; WHT 2100, Moray Estate, Rajamally, elevation 1370 $\mathrm{m}\left(06^{\circ} 48^{\prime} \mathrm{N} \& 80^{\circ} 31^{\prime} \mathrm{E}\right)$; WHT 5472, Dayagama Estate, 3rd division, Dayagama, elevation 1830m $\left(06^{\circ} 50^{\prime} \mathrm{N} \& 80^{\circ} 40^{\prime} \mathrm{E}\right)$.

Pseudophilautus auratus (Manamendra-Arachchi \& Pethiyagoda, 2005). Holotype: WHT 2356; Paratypes: WHT 2357; 2375; 2433; 2782,

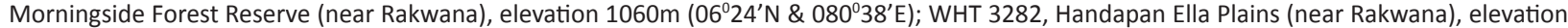
$1270 \mathrm{~m}\left(06^{\circ} 26^{\prime} \mathrm{N} \& 080^{\circ} 36^{\prime} \mathrm{E}\right)$; WHT 3298, Sinharaja World Heritage Site (near Kudawa), elevation $513 \mathrm{~m}\left(06^{\circ} 25^{\prime} \mathrm{N} \& 080^{\circ} 25^{\prime} \mathrm{E}\right)$.

Pseudophilautus bambaradeniyai Wickramasinghe, Vidanapathirana, Rajeev, Ariyarathne, Chanaka, Priyantha, Bandara \& Wickramasinghe, 2013. Holotype: NMSL 2013.01.01 NH; Paratypes: DWC 2013.01.001; DWC 2013.01.002, Sripada, (Peak Wilderness), Ratnapura District, elevation $1334 \mathrm{~m}\left(06^{\circ} 48^{\prime} 31.38^{\prime \prime} \mathrm{N}, 080^{\circ} 28^{\prime} 14.46^{\prime \prime} \mathrm{E}\right)$.

Pseudophilautus caeruleus (Manamendra-Arachchi \& Pethiyagoda, 2005). Holotype: WHT 2514; Paratypes: WHT 2511; 2512; 2513, Bogawanthalawa-Balangoda road (near Udugama), elevation 810 m (06 $\left.44^{\prime} \mathrm{N} \& 80^{\circ} 41^{\prime} \mathrm{E}\right)$; WHT 2101A; 2101B, Moray Estate, Rajamally, elevation $1370 m\left(06^{\circ} 48^{\prime} N \& 80^{\circ} 31^{\prime} E\right)$

Pseudophilautus cavirostris (Günther, 1869). Holotype: BMNH 1947.2.7.83, southern Ceylon (southern Sri Lanka); WHT 1294, Haycock (Hiniduma, Galle), elevation 660m (06 $\left.20^{\prime} \mathrm{N} \& 80^{\circ} 18^{\prime} \mathrm{E}\right)$; WHT 3299; 3300, Sinharaja World Heritage Site, Weddagala, elevation 513m (06 $25^{\prime} \mathrm{N} \&$

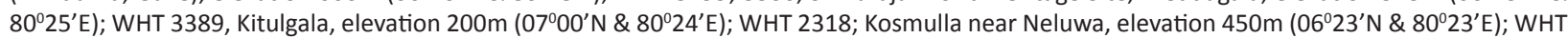

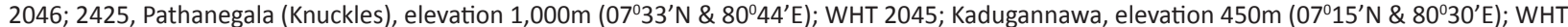
3483; Pussellawe, elevation $986 \mathrm{~m}\left(07^{\circ} 00^{\prime} \mathrm{N} \& 08^{\circ} 54^{\prime} \mathrm{E}\right)$.

Pseudophilautus cuspis (Manamendra-Arachchi \& Pethiyagoda, 2005). Holotype: WHT 1177(e); Paratypes: WHT 1177(a); 1177(b); 1177(c); 1177(d); 1177(f); 1177(g); 1177(h); 1177(i); 1177(j), Koskulana (near Panapola), elevation 460m (06 25' N \& $\left.080^{\circ} 27^{\prime} \mathrm{E}\right)$.

Pseudophilautus dayawansai Wickramasinghe, Vidanapathirana, Rajeev, Ariyarathne, Chanaka, Priyantha, Bandara \& Wickramasinghe, 2013. Holotype: NMSL 2013.02.01 NH; Paratypes: DWC 2013.01.003; DWC 2013.01.004, Sripada (Peak Wilderness), Ratnapura District, elevation 1680m $\left(06^{\circ} 48^{\prime} \mathrm{N} 080^{\circ} 29^{\prime} \mathrm{E}\right)$.

Pseudophilautus decoris (Manamendra-Arachchi \& Pethiyagoda, 2005). Holotype: mature female, 23.9mm SVL, WHT 2358; Paratypes: WHT 3194; 3257; 3258; 3265; 3266; 3267; 3268; 3269; 3271; 3270; 3272; Morningside Forest Reserve (near Rakwana), elevation 1060m (06²4’ $\mathrm{N}$ $\left.080^{\circ} 38^{\prime} \mathrm{E}\right)$.

Pseudophilautus femoralis (Günther, 1864). Holotype: 1947.2.26.89, Ceylon (Sri Lanka); WHT2701; 2702; 2703; 2704; 2705; 2706; 2707; 3540; 3537; 3538; 3539; 2478; 2479, 7.vi.1999, Horton Plains National Park, elevation $2135 \mathrm{~m}\left(06^{\circ} 46^{\prime} \mathrm{N} \& 80^{\circ} 47^{\prime} \mathrm{E}\right)$

Pseudophilautus fergusonianus (Ahl, 1927). Holotype: BMNH 1947.2.27.61, Ceylon (Sri Lanka); WHT 731; 2233, Kumaradola, Monaragala,

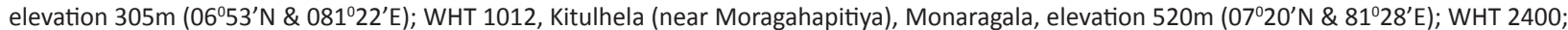

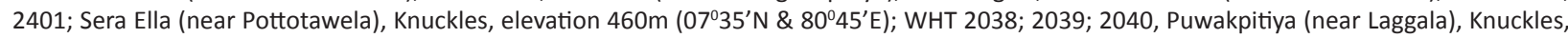
elevation 450m ( $\left.07^{\circ} 34^{\prime} \mathrm{N} \& 80^{\circ} 45^{\prime} \mathrm{E}\right)$; WHT 3360, Deniyaya, elevation 460m (06 $21^{\prime} \mathrm{N}$ \& $\left.080^{\circ} 34^{\prime} \mathrm{E}\right)$; WHT 3361; 3362; 3363; 3364; 3365, Pitadeniya (near Watugala), elevation 320m $\left(06^{\circ} 22^{\prime} \mathrm{N} \& 080^{\circ} 28^{\prime} \mathrm{E}\right)$ WHT 3168; 3177; 3195, Gannoruwa Forest reserve, Kandy, elevation 684m (07 $17^{\prime} \mathrm{N} \&$ 080 35'E); WHT 3178; 3179; 27; 3180; 3181; 3182, Puwakpitiya, Knuckles, elevation 414m $\left(07^{\circ} 34^{\prime} \mathrm{N} \& 080^{\circ} 44^{\prime} \mathrm{E}\right)$; WHT 3229, Hantana, Kandy, elevation 600m (070 $\left.15^{\prime} \mathrm{N} \& 080^{\circ} 37^{\prime} \mathrm{E}\right)$; WHT 3380; WHT 3381; NMSL 2006.64.1, Medapitiya, Wasgamuwa.

Pseudophilautus folicola (Manamendra-Arachchi \& Pethiyagoda, 2005). Holotype: mature female, 29.4mm SVL, WHT 2645; Paratypes: WHT 2646; 2647; 2649; 2650; 2651; 2652, Kottawa (Galle), elevation 60m (0606’ N \& $\left.080^{\circ} 20^{\prime} \mathrm{E}\right)$.

Pseudophilautus frankenbergi (Meegaskumbura \& Manamendra-Arachchi, 2005). Holotype: WHT 2554; Paratypes: WHT 2551; 2552; 2555; 2556, Namunukula Peak, elevation $1980 \mathrm{~m}\left(06^{\circ} 56^{\prime} \mathrm{N} \& 081^{\circ} 07^{\prime} \mathrm{E}\right)$; WHT 2726; 2727; 2728; Horton Plains National Park, elevation 2135m (06 $46^{\prime} \mathrm{N}$ \& $\left.081^{\circ} 07^{\prime} \mathrm{E}\right)$.

Pseudophilautus fulvus (Manamendra-Arachchi \& Pethiyagoda, 2005). Holotype: WHT 2949; Paratypes: WHT 2948, Laggala (Knuckles), elevation $1220 \mathrm{~m}\left(07^{\circ} 33^{\prime} \mathrm{N} \& 080^{\circ} 44^{\prime} \mathrm{E}\right)$; WHT 3112; 3114; 3463, Moussakanda, Gammaduwa, Knuckles, elevation 915m (07034'N \& 080²'E); WHT 3121; Puwakpitiya (near Laggala), Knuckles, elevation 450m (07034' $\left.\mathrm{N} \& 080^{\circ} 45^{\prime} \mathrm{E}\right)$.

Pseudophilautus hallidayi (Meegaskumbura \& Manamendra-Arachchi, 2005). Holotype: WHT 3575; Paratypes; WHT 3573; 3576; 3577, Hanthana range, Kandy, elevation $510-800$ m (070 $\left.15^{\prime} \mathrm{N} \& 080^{\circ} 34^{\prime} \mathrm{E}\right)$; WHT 6072, Tonacombe Estate, Namunukula, elevation $1320 \mathrm{~m}\left(06^{\circ} 52^{\prime} \mathrm{N} \&\right.$ $\left.081^{\circ} 07^{\prime} \mathrm{E}\right)$.

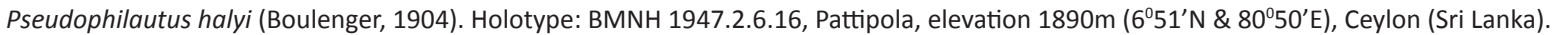

Pseudophilautus hoffmanni (Meegaskumbura \& Manamendra-Arachchi, 2005). Holotype: WHT 6120; Paratypes: WHT 3222; 3223; 3542, Corbett's Gap (Knuckles Hills), elevation $1245 \mathrm{~m}\left(07^{\circ} 22^{\prime} \mathrm{N} \& 80^{\circ} 51^{\prime} \mathrm{E}\right)$.

Pseudophilautus hoipolloi (Manamendra-Arachchi \& Pethiyagoda, 2005). Holotype: WHT 2673; Paratypes: WHT 2674; 2675, Haycock

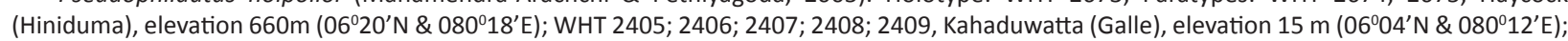

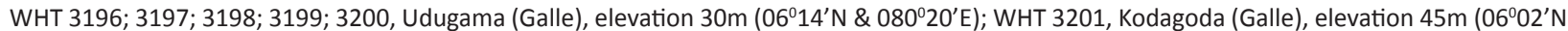
\& $\left.080^{\circ} 23^{\prime} \mathrm{E}\right)$.

Pseudophilautus hypomelas (Günther, 1876). Lectotype BMNH 1947.2.27.8, Ceylon (Sri Lanka); Paralectotypes: BMNH 1947.2.7.47; BMNH 1947.2.7.48; BMNH 1947.2.7.49; BMNH 1947.2.7.50; BMNH 1947.2.7.51; BMNH 1947.2.7.52; BMNH 1947.2.7.53; BMNH 1947.2.7.54; BMNH 1947.2.7.55; BMNH 1947.2.7.56; BMNH 1947.2.7.57, Ceylon (Sri Lanka). BMNH 1947.2.27.9; BMNH 1947.2.27.10, Le Vallon Estate in Nilambe District, Ceylon (Sri Lanka).

Pseudophilautus jagathgunawardanai Wickramasinghe, Vidanapathirana, Rajeev, Ariyarathne, Chanaka, Priyantha, Bandara \& Wickramasinghe, 2013. Holotype: NMSL 2013.03.01 NH; Paratypes: DWC 2013.01.005; DWC 2013.01.006, Sripada (Peak Wilderness), Ratnapura District, elevation $1640 \mathrm{~m}\left(06^{\circ} 48^{\prime} \mathrm{N} \& 080^{\circ} 29^{\prime} \mathrm{E}\right)$.

Pseudophilautus karunarathnai Wickramasinghe, Vidanapathirana, Rajeev, Ariyarathne, Chanaka, Priyantha, Bandara \& Wickramasinghe, 2013. Holotype: NMSL 2013.04.01 NH; Paratypes: DWC 2013.01.007; DWC 2013.01.008, Sripada (Peak Wilderness), Ratnapura District, elevation 
$1335 \mathrm{~m}\left(06^{\circ} 48^{\prime} \mathrm{N} \& 080^{\circ} 28^{\prime} \mathrm{E}\right)$.

Pseudophilautus limbus (Manamendra-Arachchi \& Pethiyagoda, 2005). Holotype: WHT 2700; Haycock, elevation 560m (06²0'N \& 080¹8'E). Pseudophilautus lunatus (Manamendra-Arachchi \& Pethiyagoda, 2005). Holotype: WHT 3283; Handapan Ella Plains, elevation 1270m $\left(06^{\circ} 26^{\prime} \mathrm{N} \& 080^{\circ} 36^{\prime} \mathrm{E}\right)$

Pseudophilautus macropus (Günther, 1869). Holotype: BMNH 1947.2.8.78, southern Ceylon (southern Sri Lanka); WHT 3390; 3391; 3392; 3393; 3394; 3395; 3396; 3397; 3398; 3399; 3400; 3401; 3402; 3403; 3404; 3405; 3406, Mousakanda (Gammaduwa), Knuckles, elevation 760m

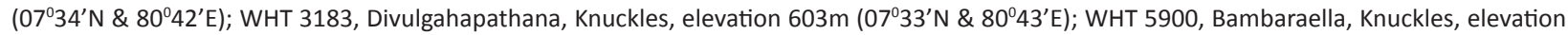
$1260 \mathrm{~m}\left(07^{\circ} 24^{\prime} \mathrm{N} \& 80^{\circ} 47^{\prime} \mathrm{E}\right)$.

Pseudophilautus maia (Meegaskumbura, Manamendra-Arachcchi, Schneider \& Pethiyagoda, 2007). Holotype: BMNH 76.3.21.18; Paratype: BMNH 76.3.21.19. Both Holotype and Paratype collected at “Poojagodde” (Poojagoda) Estate, Ramboda, Sri Lanka.

Pseudophilautus microtympanum (Günther, 1859). Lectotype: BMNH 1947.2.8.48, Ceylon (Sri Lanka), WHT 2710; 2708; 2712; 2713; 3436; 3437; 3438; 3439; 3440; 3441; 3442; 3443; 3444; 3446, Horton Plains National Park, elevation 2135m (06 $\left.{ }^{\circ} 46^{\prime} \mathrm{N} \& 80^{\circ} 47^{\prime} \mathrm{E}\right)$; WHT 3260, Agra Arboretum, near Agarapatana, elevation 1555m (06 $\left.51^{\prime} \mathrm{N} \& 80^{\circ} 41^{\prime} \mathrm{E}\right)$.

Pseudophilautus mittermeieri (Meegaskumbura \& Manamendra-Arachchi, 2005). Holotype: WHT 3522; Paratypes: WHT 3523; 3524; 3525; 3526, Kottawa, Galle, elevation $60 \mathrm{~m}\left(06^{\circ} 06^{\prime} \mathrm{N} \& 080^{\circ} 20^{\prime} \mathrm{E}\right)$; WHT 2668, Beraliya forest, Elpitiya, elevation $150 \mathrm{~m}\left(06^{\circ} 16^{\prime} \mathrm{N} \& 080^{\circ} 11^{\prime} \mathrm{E}\right)$. Pseudophilautus mooreorum (Meegaskumbura \& Manamendra-Arachchi, 2005). Holotype: WHT 5862; Paratypes: WHT 5868; 5869, Hunnasgiriya (Knuckles), elevation $1100 \mathrm{~m}\left(07^{\circ} 23^{\prime} \mathrm{N} \& 080^{\circ} 41^{\prime} \mathrm{E}\right)$; WHT 2477; 3209; 6124, Corbett's Gap (Knuckles), $1245 \mathrm{~m}\left(07^{\circ} 22^{\prime} \mathrm{N} \& 080^{\circ} 51^{\prime} \mathrm{E}\right)$. Pseudophilautus nanus (Günther, 1869). Lectotype: BMNH 1947.2.7.78; BMNH 1947.2.7.79, BMNH 1947.2.7.82, BMNH 1947.2.7.86, southern Ceylon (southern Sri Lanka) Pseudophilautus nasutus (Günther, 1869). Holotype: BMNH 1947.2.6.21, Ceylon (Sri Lanka). Pseudophilautus nemus (Manamendra-Arachchi \& Pethiyagoda, 2005). Holotype: WHT 1319; Haycock (Hiniduma), elevation 660m (06 $20 ` \mathrm{~N}$ \& $080^{\circ} 18^{\prime} \mathrm{E}$ )

Pseudophilautus newtonjayawardanei Wickramasinghe, Vidanapathirana, Rajeev, Ariyarathne, Chanaka, Priyantha, Bandara \& Wickramasinghe, 2013. Holotype: NMSL 2013.05.01 NH, Sripada (Peak Wilderness), Ratnapura District, $1560 \mathrm{~m}\left(06^{\circ} 48^{\prime} \mathrm{N} 080^{\circ} 28^{\prime} \mathrm{E}\right)$. Pseudophilautus ocularis (Manamendra-Arachchi \& Pethiyagoda, 2005). Holotype: WHT 2360; Paratypes: WHT 3273; 2376; 2377; 2378, Morningside Forest Reserve (near Rakwana), elevation 1060m (06²2‘`N \& 080³8`E); WHT 3288; 3289; 3290; 3291; 3292; 3293, Handapan Ella Plains (near Suriyakanda), elevation $1270 \mathrm{~m}\left(06^{\circ} 26^{\prime} \mathrm{N} \& 080^{\circ} 36^{\prime} \mathrm{E}\right)$.

Pseudophilautus oxyrhynchus (Günther, 1872). Lectotype of Ixalus oxyrhynchus (here designated), mature female, 18.6mm SVL, BMNH 1947.2.6.40, 'Ceylon', coll. K.G.H.K. Thwaites.

Pseudophilautus papillosus (Manamendra-Arachchi \& Pethiyagoda, 2005). Holotype: WHT 3284; Handapan Ella Plains (near Rakwana), elevation $1270 \mathrm{~m}\left(06^{\circ} 26^{\prime} \mathrm{N} \& 080^{\circ} 36^{\prime} \mathrm{E}\right)$

Pseudophilautus pardus (Meegaskumbura, Manamendra-Arachcchi, Schneider \& Pethiyagoda, 2007). Holotype: BMNH 1947.2.7.96. Pseudophilautus pleurotaenia (Boulenger, 1904). BMNH 1947.2.7.64, Kandy, Sri Lanka; WHT 3176; 5824; Gannoruwa Forest reserve, Kandy, elevation 684m (07017'N \& 080 35'E); WHT 5860; 5861; Nawalapitiya, elevation $700 \mathrm{~m}\left(07^{\circ} 03^{\prime} \mathrm{N} \& 080^{\circ} 32^{\prime} \mathrm{E}\right)$.

Pseudophilautus poppiae (Meegaskumbura \& Manamendra-Arachchi, 2005). Holotype: WHT 3285; Handapan Ella Plains (near Suriyakanda), elevation $1270 \mathrm{~m}\left(06^{\circ} 26^{\prime} \mathrm{N} \& 080^{\circ} 36^{\prime} \mathrm{E}\right)$; Paratypes: WHT 2030; 2029; 2475; 2778; 2781; 3533; 3534; 3535; 3536, Morningside (near Rakwana), elevation $1060 \mathrm{~m}\left(06^{\circ} 24^{\prime} \mathrm{N} \& 080^{\circ} \mathrm{E}\right)$

Pseudophilautus procax (Manamendra-Arachchi \& Pethiyagoda, 2005). Holotype: WHT 3279; Paratypes: WHT 2786; 2787; 3277; 3278; 3280; 3281, Morningside Forest Reserve (near Rakwana), elevation $1060 \mathrm{~m}\left(06^{\circ} 24^{\prime} \mathrm{N} \& 080^{\circ} 38^{\prime} \mathrm{E}\right)$.

Pseudophilautus regius (Manamendra-Arachchi \& Pethiyagoda, 2005). Holotype: WHT 3122; Paratypes: WHT 5827; 5828; 5829, Angammadilla, Polonnaruwa, elevation $90 \mathrm{~m}\left(07^{\circ} 51^{\prime} \mathrm{N} \& 080^{\circ} 55^{\prime} \mathrm{E}\right)$.

Pseudophilautus reticulates (Günther, 1864). Holotype: BMNH 1947.2.8.60, Ceylon, (Sri Lanka); WHT 2286; 2287; 2290; 2291, Kosmulla (near Nelluwa), elevation 320m ( $\left.06^{\circ} 24^{\prime} \mathrm{N} \& 80^{\circ} 23^{\prime} \mathrm{E}\right)$; WHT 2288; 2289, Dediyagala Forest Reserve, Akuressa, elevation $150 \mathrm{~m}\left(06^{\circ} 10^{\prime} \mathrm{N} \& 80^{\circ} 26^{\prime} \mathrm{E}\right)$; WHT 2344, Yagirala, elevation 30m (06 $\left.22^{\prime} \mathrm{N} \& 80^{\circ} 10^{\prime} \mathrm{E}\right)$; WHT 3230, Induruwa, (Ratnapura), elevation 150m (06 $\left.45^{\prime} \mathrm{N} \& 80^{\circ} 26^{\prime} \mathrm{E}\right)$; NMSL 2006.66.1; Gileemale forest, elevation $150 \mathrm{~m}\left(06^{\circ} 45^{\prime} \mathrm{N} \& 080^{\circ} 26^{\prime} \mathrm{E}\right)$; WHT 2520; 2521, Check Poleat Gap (near Norton Bridge), elevation 800m (06 $56^{\prime} \mathrm{N} \&$ $80^{\circ} 30^{\prime} \mathrm{E}$ ); WHT 3366, Haycock (Hiniduma), elevation 660m $\left(06^{\circ} 20^{\prime} \mathrm{N} \& 80^{\circ} 18^{\prime} \mathrm{E}\right)$

Pseudophilautus rus (Manamendra-Arachchi \& Pethiyagoda, 2005). Holotype: WHT 3474; Paratypes: WHT 3475; 3476; WHT 3477, Kiribatkumbura (near Peradeniya), elevation 450m (07¹6’ N \& 080³4'E); WHT 5437; 5439; 5436; WHT 5440; 5438; 5432; 5435; 5434, Pilimatalawa (near Peradeniya), elevation 658m $\left(07^{\circ} 15^{\prime} \mathrm{N} \& 080^{\circ} 34^{\prime} \mathrm{E},\right)$.

Pseudophilautus samarakoon Wickramasinghe, Vidanapathirana, Rajeev, Ariyarathne, Chanaka, Priyantha, Bandara \& Wickramasinghe, 2013. Holotype: NMSL 2013.07.01 NH; Paratypes: DWC 2013.01.011; DWC 2013.01.012, Sripada (Peak Wilderness), Ratnapura District, elevation 1335m

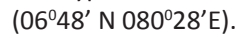

Pseudophilautus sarasinorum (Müller, 1887). WHT 2480; 2481; 2482; 2483, Bogawanthalawa-Balangoda road, elevation 1300m (0645’ N \& $\left.080^{\circ} 42^{\prime} \mathrm{E}\right)$; WHT 2426; 2427; 2428; 2429, Corbett's Gap, elevation $1000 \mathrm{~m}$ (07²2 ' N \& 080 $\left.50^{\prime} \mathrm{E}\right)$.

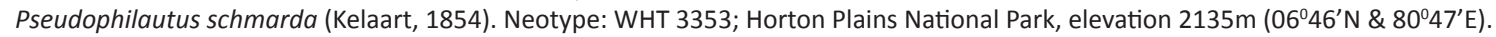

Pseudophilautus silus (Manamendra-Arachchi \& Pethiyagoda, 2005). Holotype: WHT 3453; Paratypes: WHT 3451; WHT 3452; WHT 3454; WHT 3460,Agra Arboretum, near Agarapatana, elevation 1555m (06 $\left.51^{\prime} \mathrm{N} \& 080^{\circ} 41^{\prime} \mathrm{E}\right)$; WHT 3412, Tangamalai Sanctuary, near Haputale, elevation $1600 \mathrm{~m}\left(06^{\circ} 46^{\prime} \mathrm{N} \& 080^{\circ} 55^{\prime} \mathrm{E}\right)$;

Pseudophilautus silvaticus (Manamendra-Arachchi \& Pethiyagoda, 2005). Holotype: WHT 3295; Paratypes: WHT 3296, 3378; 3379; 3461; 3462, Handapan Ella Plains (near Suriyakanda), elevation $1270 \mathrm{~m}\left(06^{\circ} 26^{\prime} \mathrm{N} \& 080^{\circ} 36^{\prime} \mathrm{E}\right)$; WHT 3275; WHT 3276, Morningside Forest Reserve (near Rakwana), elevation $1060 \mathrm{~m}\left(06^{\circ} 24^{\prime} \mathrm{N} \& 080^{\circ} 38^{\prime} \mathrm{E}\right)$; WHT 3310; 3316, Sinharaja World Heritage Site (near Kudawa), elevation 513m (06 $25^{\prime} \mathrm{N} \&$ $\left.080^{\circ} 25^{\prime} \mathrm{E}\right)$.

Pseudophilautus simba (Manamendra-Arachchi \& Pethiyagoda, 2005). Holotype: WHT 3464; Paratypes: WHT 3465; WHT 3466; WHT 3467, Morningside Forest Reserve (near Rakwana), elevation $1060 \mathrm{~m}\left(06^{\circ} 24^{\prime} \mathrm{N} \& 080^{\circ} 38^{\prime} \mathrm{E}\right)$.

Pseudophilautus sirilwijesundarai Wickramasinghe, Vidanapathirana, Rajeev, Ariyarathne, Chanaka, Priyantha, Bandara \& Wickramasinghe,

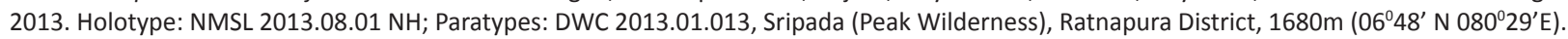

Pseudophilautus sordidus (Manamendra-Arachchi \& Pethiyagoda, 2005). Holotype: WHT 2379; Paratypes: WHT 2383; 2384; 2385; 2386;

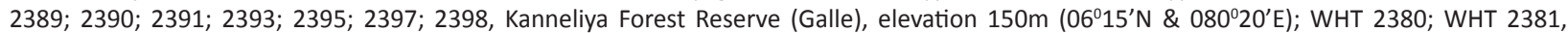
Haycock (Hiniduma), elevation 660 m (06 $\left.20^{\prime} \mathrm{N} \& 080^{\circ} 18^{\prime} \mathrm{E}\right)$; WHT 2382, Haycock (Hiniduma), elevation 150m (06 $\left.18^{\prime} \mathrm{N} \& 080^{\circ} 19^{\prime} \mathrm{E}\right) ; 2387 ; \mathrm{WHT}$ 
2396, Millawa Forest Reserve (near Morawaka), elevation 150m (06²17'N \& 080²8'E); WHT 2988, Welikanna, Waga (near Labugama), elevation

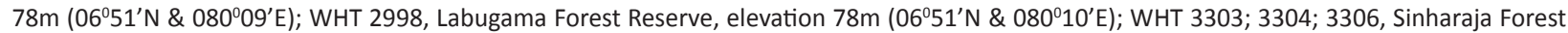
Reserve (Halmandiya), elevation 513m (06² $\left.25^{\prime} \mathrm{N} \& 080^{\circ} 25^{\prime} \mathrm{E}\right)$; NMSL 2006.65.1. Denenakanda, Peak Wilderness.

Pseudophilautus steineri (Meegaskumbura \& Manamendra-Arachchi, 2005). Holotype: WHT 3210; Paratypes: WHT 3519; 3521; 3520, 6116;

3518, Corbett's Gap (Knuckles Hills), elevation $1245 \mathrm{~m}\left(07^{\circ} 22^{\prime} \mathrm{N} \& 080^{\circ} 51^{\prime} \mathrm{E}\right)$.

Pseudophilautus stictomerus (Günther, 1876). WHT 1173; 2402, Kottawa (Galle), elevation 60m (06 $\left.06^{\prime} \mathrm{N} \mathrm{\&} 080^{\circ} 20^{\prime} \mathrm{E}\right)$; WHT 2403; 2404 , Kanneliya (Galle), elevation 150m (06 $\left.15^{\prime} \mathrm{N} \& 080^{\circ} 20^{\prime} \mathrm{E}\right)$; WHT 3301, Sinharaja Forest (near Kudawa), elevation 513m (06 $\left.25^{\prime} \mathrm{N} \& 080^{\circ} 25^{\prime} \mathrm{E}\right)$; WHT 3355; 3356; 3357; 3358; 3359, Kosmulla (near Nelluwa), elevation 320m (06 $\left.24^{\prime} \mathrm{N} \& 080^{\circ} 23^{\prime} \mathrm{E}\right)$.

Pseudophilautus stuarti (Meegaskumbura \& Manamendra-Arachchi, 2005). Holotype: WHT 3208; Paratypes: WHT 3207; 3206; 3218, 3527, 357 Corbett's Gap (Knuckles Hills), elevation $1245 \mathrm{~m}\left(07^{\circ} 22^{\prime} \mathrm{N} \& 080^{\circ} 51^{\prime} \mathrm{E}\right)$.

Pseudophilautus temporalis (Günther, 1864). Lectotype: BMNH 1947.2.6.9; Paralectotypes: BMNH 1947.2.6.8, BMNH 1947.2.6.10. Ceylon, (Sri Lanka).

Pseudophilautus variabilis (Günther, 1859). Lectotype: BMNH 1947.2.7.87, Ceylon (Sri Lanka).

Pseudophilautus viridis (Manamendra-Arachchi \& Pethiyagoda, 2005). Holotype: WHT 5127; Paratypes: WHT 3488; 3489; 5104; 5105; 5106; 5099; 5100; 5103; 5126, Agra Arboretum, near Agarapatana, elevation 1555m (06 $51^{\prime} \mathrm{N}$ \& $\left.080^{\circ} 41^{\prime} \mathrm{E}\right) ;$ WHT 2763; 2764; 2765; 2766; 2767; 2768, 4999, Ambewela (near radio station), elevation 1830m (06053’ N \& $\left.080^{\circ} 48^{\prime} \mathrm{E}\right)$.

Pseudophilautus zal (Manamendra-Arachchi \& Pethiyagoda, 2005). Holotype: BMNH 1947.2.8.45.

Pseudophilautus zorro (Manamendra-Arachchi \& Pethiyagoda, 2005). Holotype: WHT 3169; Paratypes: WHT 3175; 3204; 3205, Gannoruwa Forest Reserve, Kandy, elevation $684 \mathrm{~m}\left(07^{\circ} 17^{\prime} \mathrm{N} \& 080^{\circ} 35^{\prime} \mathrm{E}\right)$; WHT 3508 , Tiverton Estate (near Peradeniya), elevation $450 \mathrm{~m}\left(07^{\circ} 16^{\prime} \mathrm{N} \& 080^{\circ} 34^{\prime} \mathrm{E}\right)$.

Appendix 2. The description of "Ixalus hypomelas," on page 380 of Albert Günther, 1876, Notes on the mode of propagation of some Ceylonese tree-frogs, with description of two new species, Ann. \& Mag. Nat. Hist. (ser. 4) 17(101): 377-380:

\section{Ixalus hypomelas.}

"Snout not flattened, of moderate length, somewhat rounded in front, with distinct canthus rostralis, and with the loreal region subvertical. Eye of moderate size; tympanum hidden. Skin smooth. Metatarsus without fringe or fold, and with a single tubercle. Fingers not webbed; web of the hind foot rudimentary. Disks rather small. The length of the body is scarcely equal to the distance of the vent from the heel. Coloration varies: the most characteristic form is chocolate-brown above, with the sides and lower parts black, spotted with white; a fine white line runs along the middle of the back and of the abdomen, beginning from the snout, the abdominal line being frequently crossed by another white line, running from one fore leg to the other; metatarsus with a white line along its outer margin. All or some of these lines may be absent. Sometimes the upper parts are dark purplish (the snout being of a lighter colour) or purplish grey mottled with brown. In one variety, in which all the white lines are absent, the upper part of the snout as well as of the forearm is of a uniform greyish-white colour.

"The largest of several specimens is 22 millims. long, the hind limb being 35 millims. We have received specimens of this species in Col. Beddome's and Mr. Ferguson's collections."

Appendix 3. Important short note of "IXALUS HYPOMELAS", on page 29 of W. Ferguson, 1877, Letter on a collection sent to the Colombo Museum, Reptile Fauna of Ceylon.

"164-IXALUS HYPOMELAS, Gthr. Two specimens. This is a remarkable and beautiful little frog; described lately by Dr. Günther, from specimens sent to him by Col. Beddome and myself. My specimens were caught in the forest at Le Vallon Estate in Nilambe District".

\section{Author Details:}

L.J. Mendis Wickramasinghe, is the founder, President of the Herpetological Foundation of Sri Lanka, and is the Principal Investigator in the current project. He has close to two decades of field herpetological (reptile and amphibian) experience in Sri Lanka with a focus on taxonomic identifications, and also providing education and awareness to the general public on Venomous Snakes in the island. He has contributed his expertise towards national projects on identification of threatened species in Sri Lanka, and has facilitated the declaration of several protected areas in Sri Lanka. A member of the Experts Committee on herpetofauna in Sri Lanka, under the National Species Conservation Advisory Group (NSCAG), and in several international bodies including several Species Survival Commission groups of the International Union for Conservation of Nature (IUCN/SSC).

DULAN RANGa VIDANAPATHIRANA, is the Vice-President, and a founder member of the Herpetological Foundation of Sri Lanka, with over 10 years of field herpetological, and birding experience in Sri Lanka, where he is also a Natural History Tour Leader at the Bird and Wildlife Team. Currently working in several projects on herpetology in the country at the HFS.

M. D. GeHAN RAJEEV, is working as a Medical Doctor at General Hospital, Kanthale. Is a naturalist with an interest in writing and photography currently involved in herpetofaunal research at the Herpetological Foundation Sri Lanka, involved in field data gathering. Member of the Young Zoologist's Association of Sri Lanka, and working to conserve the wildlife in the Island.

Nethu Wickramasinghe, is the Projects co-ordinator, at the Herpetological Foundation of Sri Lanka, completed the basic degree in chemistry at the University of Delhi. Currently a freelance Science journalist, contributing to the dissemination of the conservation aspects of herpetofauna to the general public. 